Relations industrielles

Industrial Relations

\title{
Teamwork in Industry
}

\section{Labour-Management Production Committees}

Volume 6, numéro 4, septembre 1951

URI : https://id.erudit.org/iderudit/1023143ar

DOI : https://doi.org/10.7202/1023143ar

Aller au sommaire du numéro

Éditeur(s)

Département des relations industrielles de l’Université Laval

ISSN

0034-379X (imprimé)

1703-8138 (numérique)

Découvrir la revue

Citer cet article

(1951). Teamwork in Industry: Labour-Management Production Committees. Relations industrielles / Industrial Relations, 6(4), 117-122.

https://doi.org/10.7202/1023143ar

Tous droits réservés (C Département des relations industrielles de l’Université Laval, 1951
Ce document est protégé par la loi sur le droit d'auteur. L’utilisation des services d'Érudit (y compris la reproduction) est assujettie à sa politique d'utilisation que vous pouvez consulter en ligne.

https://apropos.erudit.org/fr/usagers/politique-dutilisation/ 
clerk's office of the court of conciliation of the place where deposit has been made to the collectice agreement or of one of the agreements referred to in section 31 of volume 1 of the Labour Code, or section 21 of this Act or, failing agreements, of the place where they were rendered. Such deposit is made, at common costs, as regards the conciliation agreement, by the most diligent party and, as regards the arbitrator. Once deposited, the agreement or award has the force of law. Orders and awards of the Higher Court of Arbitration are published every three months in the Journal officiel."

"Sec. 17. - When ever a conciliation agreement or arbitral award having force of law relates to the interpre'ation of clauses of an existing collective agreement, to wages or working conditions, such agreement or award, providing it is deposited as mentioned in section 16, shall have the same effect as that of a collective industrial agreement. Should the agreement or award be entered into for the purpose of settling a dispute which has arisen in a branch of activity covered by a collective agreement extended under section $31-j$ or volume 1 of the Labour Code, such agreement or award shall, upon request from the organisations parties to the extended collective agreement, be extended by an order under the provisions of sections $31-i, 31-k$ and $31-1$ of volume 1 of the Labour Code. Such order may be reported as provided for under the second paragraph of section $31-\mathrm{m}$ of volume 1 of the Labour Code. The provisions of article VIII, chapter IV bis of part II of volume 1 of the Labour Code, apply to conciliation agreements as well as to arbitral awards covered by an order of extension. There shall be no charge for the registration of any action taken under the provisions of the present part."

\section{Teamwork in Industry *}

\section{Labour-Management Production Committees}

An animated colony film which points the way to more harmonious labcur-management relations was recently given its Canadian premiere in an Ottawa theatre.

Invitations to attend the screening came from the Hon. Milton F. Gregg, federal Minister of Labour, for whose department the film was produced.

The film, "Tearnwork, Past and Present", traces the growth of cooperation among men from the beginning of history, pointing out its benefits and the part it has played in the spread of civilization. It shows how, with the ever-growing increase in the size of industrial establishments, the worker lost practically all opportunity for creative expression, found he no longer had an outlet for his ideas, and, feeling frustrated, became discontented with his lot. It shows, too. how the workers turned to the trade union movement in in-

* Article prepared in the Federal Department of Labour, Ottawa. creasing numbers until it became strong enough to stand in opposition to owners and management, a situation more likely to erupt into strike than to progress to partnership.

Into this situation, as the film then portrays, there entered an idea, that of co-operation and consultation between the two participants in industry. The idea was not a new one. As the film shows, it had its birth early in man's history; but it was forgotten in the rush of rapid industrialization. It was the method of applying the idea which was new. The film's final minutes are devoted to encouragement for this new method.

The method? Labour-Management Production Committees, whose voluntary establishment in Canadian industrv is promoted by the Government of Canada through the LabourManagement Co-operation Service of the Industrial Relations Branch, Department of Labour.

A Labour-Management Production Committee, LMPC for short, is a 
committee composed of Labour and Management representatives in a plant where collective bargaining is practised between management and a bona fide union, or some other form of employee organization which has been certified by the appropriate Labour Relations Board. It deals with matters of mutual interest other than those classed as collective bargaining items, i.e., wages, hours and grievances.

An LMPC is an additional channel for the exchange of ideas and information on a plant's everyday problems. LMPCs are among the best expressions of industrial democracy. They depend for their effectiveness on education, co-operation and selfdiscipline, which are at the root of all democratic action. Their voluntary nature makes them much more effective than any form of direction which is imposed from above, a practice being followed in many oppressed countries today.

The Canadian government encourages the estiblishment of these committees because of the contribution they can make to the country's economic position and to industrial peace. The work of the Labour-Management Co-operation Service is endorsed by the major employer organizations and trade union groups, including the Canadian and Catholic Confederation of Labour. The Labour-Management Co-operation Service assists managements and trade unions in the establishment of LMPCs, advises established committees which encounter difficulties, provides a variety of publicity material for LMPCs to use in their operations, and periodically makes research studies of outstanding committees.

At the present time, there are in Canada 746 LMPCs established in conformation with the pattern recommended by the Labour-Management Co-operation Service. These represent more than 300,000 workers. Of the 746 LMPCs, 153 are in the province of Quebec.

Labour-Management Production Committees were widely adopted by the democratic allies during the Second World War. During the war, the major purpose of LMPCs was to increase production, at that time a desperate need in order to equip and supply the armed forces. In fact, LMPCs were primarily and originally intended to serve as a production tool, a means by which to increase output by bringing the knowledge, experience, and ideas of everyone participating in the enterprise to bear on the problems which hinder or hamper production: inefficient work methods, waste of material and time, accidents, absenteeism, poor lighting and ventilation, duplication of effort, damaged tools, to name only a few. The fact that the establishment of an LMPC resulted in an improvement in morale was at first overshadowed by the fact that the committee had such a salutary effect on production. With the coming of peace, however, the emphasis shifted, and now it is being realized that an LMPC is more than an aid to production.

It is being realized more and more, for example, that joint consultation is an additional, and highly effective communications tool, an ideal way for spreading information about the company and the industry to the lowest levels of an organization and to the farthest corners of a factory. Evidence is ample that an LMPC greatly assists the effective dissemination of information from the top to the bottom and results in improved reception of ideas and opinions from the bottom. It is generally agreed that communication in an organization is not satisfactory if it flows in one direction only - from top to bottom. According to those who have made a thorough study of the subject, information emanating from the top rung of the organizational ladder in the form of directives, bul- 
letins, letters, pay envelope stuffers and posters - while these all have their place in a communications programme - is not received at the bottom as effectively as it should be.

A British personnel man has made a pertinent comment on this fact. Howard Marshall, director of public and personnel relations, Richard Thomas and Baldwins Ltd., said: "We're far too fond of telling people what we think they ought to know instead of realizing that true communication means a two-way bridge to mutual understanding, and ultimately to mutual effort for a common purpose".

\section{Labour-Management Production} Committee establishes such a twoway bridge. Where an LMPC is functioning properly, the worker soon finds that management, through the committee, welcomes and carefully considers his suggestions on plant operations, and, as a result, no longer feels that he is merely a name on a payroll.

Conversely, management can get information about company operations to the workers, who come to realize the problems management has to contend with. According to Stanley C. Allyn, a director of the U.S. Chamber of Commerce, "It is not enough for management to be sure that workers know what the men at the top are thinking; it is equally important for management to know what labour is thinking."

Through an LMPC, a company can tell the workers about business prospects, future expansion or rearrangement of facilities. Changes are always more readily accepted when they have been described in advance than when they are thrust upon the workers unannounced. And if the workers know that their representatives have shared in the deliberations leading up to the changes, their acceptance is even more readily forthcoming. Again Mr. Marshall has provided a pertinent comment:
"The preparation of men's minds, the advance information, the explanation which will help them to adjust themselves to new directives and unexpected situations - and, as important as anything else, the opportunity to make their own contribution towards policy, their own commentary and counsel, the products of their experience - all these are essentials of teamwork. And all are the outcome of communications which will enable any organization to make the most effective use of the varying contributions of all its employees, and at the same time to show that these contributions are being used to serve a' worthwhile purpose."

The reason why failure to provide advance information is likely to cause trouble is explained by Professor Florence Peterson, director, Graduate Department of Social Economy, Bryn Mawr College, in this way: "The introduction of a new machine may be 'rational' in terms of business improvement, but it is just as rational for those who suffer from the new method to protest its introduction. Some of the unrest could be alleviated if workers were kept fully informed of contemplated changes and were given the assurance that management was as concerned about their future as it was about the future possibilities of the new machine."

That workers are entitled to information about the company they work for, are entitled to know as much about the business as the shareholders are told, is a belief that is gaining wide acceptance nowadays. It was most recently stressed in a speech at the latest convention in Quebec of the Canadian Manufacturers' Association. Senator Wallace F. Bennett of Utah, in an address to the convention, said an employee should know what his job is all about and where he fits into the whole company process; should know cur- 
rent goals and how they are being met. Students of the industrial scene point out that the worker who is kept "in the picture" is a more contented individual - and, incidentally, a more productive one.

It is also being realized more and more that an LMPC is a medium for giving greater recognition to workers as human beings and to the natural desire of individuals for personal recognition and expression, the desire to work as co-participants rather than as superiors and subordinates. From a hurnan relations point of view, the true measure of good industrial relations is the extent to which the sense of human dignity is preserved and individual initiative is promoted.

LMPCs are also providing a vehicle for the search for understanding between capital and labour which the Bishops of Quebec urged in their joint pastoral letter. And, according to Glen U. Cleeton, professor of industrial psychology, Carnegie Institute of Technology, "the maintenance of harmonious human relations in industry requires that management and workers understand each other's points of view. Group conflict in human relations can be reduced through cultivation of mutual understanding."

For a long time the human factors in industry were neglected. T'echnology has relieved workers of much heavy, arduous drudgery, but it has also reduced the opportunity for creative expression. Consequently, the inherent challenge of work as a normal human activity is often dissipated to such an extent that many industrial jobs become dull and uninteresting, if not, indeed, frustrating. General disregard for the spiritual values of work has produced numerous situations in which greed is rampant, tensions are acute, and group conflicts are in daily evidence. To reach the heart of the problem of human relations in industry, em- ployers and workers must find a basis for developing mutual respect for the desires and needs of each other.

Among every worker's desires, in addition to his basic physical needs, are these: the urge for self-expression, the desire for personal achievement, and the need for group status. As a human being, every worker seeks a responsive social relationship with his employers and fellow-employees. He responds favourably when his surroundings promote physical well-being; when he is recognized as an individual, a partner, not a servant; when he possesses knowledge of the results of his efforts; when he is kept informed of company plans and policies; and when there is a friendly social atmosphere in which he is considered with respect. If any of these conditions are lacking, if any of these desires go unsatisfied, men will not work together with full effectiveness. A worker can only do his best when his heart is in his work, and when he can be proud of belonging to the company and knows that his work contributes to the success of the undertaking as a whole.

A properly-functioning LabourManagement Production Committee can provide all the above conditions and can satisfy the worker's desire for recognition as an individual, for status in a group and for information about his job. When workers are free to submit their ideas to management through an LMPC, when their representatives are taken into management's confidence and participate in solving the problems facing the company, they come to feel that their opinions are valued, that their job is important and that they are all members of a team co-operating to ensure the success of the enterprise.

Speaking at the annual convention of the Canadian Manufacturers' Association in Quebec in June, Labour Minister Gregg said that Labour- 
Management Production Committees "give the workers a chance to get to know the management, which ceases to be that impersonal 'they' on whom can be blamed everything that may irritate. It is being found that LMPCs foster mutual confidence and do much to kill the old idea of two opposing camps with divided interests and loyaities".

It is also being found that the existence of an LMPC in a plant gives everyone the opportunity to expose the minor irritations which, if allowed to grow and accumulate, can have a serious effect on morale. Once exposed, they can be eliminated before they are able to cause trouble.

In addition, it has been found that a by-product of Labour-management co-operation is the discovery of previously unknown and unsuspected skills and talents among employees. These, added to those of the professional managers and their technical assistants, have multiplied the creative resources of the company.

Co-operation between Labour and management through an LMPC which follows the pattern recommended by the Federal Department of Labour does not involve any sacrifice of the rights, responsibilities, or freedom of either. Neither group gives up anything. Labour does not try to take over management's jog; nor does management encroach on the union's territory. The role of the committee is purely advisory and it is left to management to implement its recommendations. Based upon a sincere recognition of each other's functions and responsibilities, an LMPC is in effect a pooling of both labour's and management's knowledge, skill, experience and abilities in a joint attack on mutual company problems.

Clinton S. Golden, long-time international vice-president of the United Steelworkers of America (CIO) and now visiting lecturer on labour problems at Harvard, has traced through three stages the evolution of labour organizations from "conspiracies" into legitimate, self-governing societies. In the first stage, the workers in a craft or industry got together to function as a cohesive group and attempted to create new institutional loyalties; in the second stage, the union organization demanded recognition as an authorized representative of the indivdiual workers who comprised its membership; and in the third stage, the union organization is accepted by management as a legitimate institution and constructive participant in the enterprise.

Among both management and union representatives are many who believe that the simple granting of recognition constitutes co-operation and that the end of, rather than another step in, the evolutionary development has been reached. This seems to imply that when two powercentered groups with differing interests are brought into an uneasy equilibrium, the task of adjustment and accommodation is largely completed.

While the collective agreement usually contains the rules governing the relationship mutually agreed to by management and union representatives of the employees, it does not automatically establish either the conditions or climate necessary for genuinely creative and constructive co-operation. This armistice form of relationship, moreover, does not by itself provide, as a rule, either management or employees with the longrange sense of security or the spiritual and other personal satisfactions that normal human beings seek from their work and associations.

An increasing number of people, on the other hand, do not accept the view that the granting of union recognition constitutes co-operation 
and are not satisfied with achieving an uneasy equilibrium of two allegedly hostile social or occupational groups. They agree that when two organized groups, upon whose existence the functioning of modern industry depends but whose interests are not completely mutual, manage to co-exist in a reasonably peaceful relationship, it represents an achievement but by no means a completely desirable and ultimate end.

These persons want to push forward in an effort to establish a harmonious and creative relationship wherein the human personality can grow and find creative expression in industry. They believe, and experience has supported their convictions, that each employee is a poten- tially valuable human resource capable of making a contribution not only to the suocess of the enterprise in which he is employed but to the hap. piness and well-being of his felloworkmen - and management associates as well.

Mr. Golden's "third stage" has not been reached everywhere, of course. Indeed, in a few instances the second stage has not yet been reached. But where management has accepted a union organization as a legitimate institution and anticipates that it will become a constructive participant in the enterprise, the next logical development would seem to be the formation of a Labour-Management Production Committee.

\title{
ARBITRATION JURISPRUDENCE
}

\author{
by JEAN-H Gagné, \\ Professor in the Faculty of Social Sciences
}

Under this heading, which will appear in every issue of the Industrial Relations Review, we shall present the principal points of interest encountered in the arbitration awards rendered by the councils of arbitration during the three months preceding the publication of each of the issues of this review.

Occasionally, we shall analyze also, under this heading, the judgments rendered by the Courts of Common Law during the same period and relevant to labour laws. The arbitration awards studied in the present issue are those rendered during the months of May, June and July, 1951. We are only reporting the awards which contain points of particular interest to our readers.

1-Regent Knitting Mills Limited, St. JEROME, AND ITS EMPLOYEES' UNION.

Jurisdiction of the arbitrators: Cost of living bonus and the period of revision of the cost of living index.

In an unanimous award, the council of arbitration, recommends that the cost-ofliving bonus be divided among the number of hours really worked by the employees; that the cost of living index be revised every three months and that it be taken into account in the readjustment of wages, either up or down.

(Union fédérale des employés du textile de St. Jérôme, Local 54; kind of enterprise: secondary textile manufacturer; $800 \mathrm{em}$ - ployees concerned out of 1,104; union affiliated with the T. L. C.; unanimous award rendered May 10th, 1951, 1951; members of council: employer's representative: Mr. Lucien Thinel; employees' representative: Mr. Maurice Fortier; president: Mr. Roger Lacoste.)

2-Besner Building, Montreal, AND eMPLOYEES' UNION.

Jurisdiction of the arbitrators: Job evaluation and establishing of a normal work week.

Job Evaluation: Here are the rates recommended by the council for the principal jobs done by employees of public buildings:

The Industrial Relations Review 